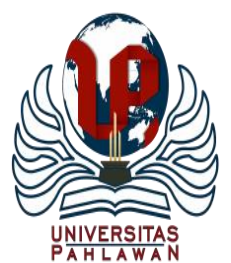

Edukatif : Jurnal Ilmu Pendidikan Volume 3 Nomor 4 Tahun 2021 Halm 2067 - 2080

EDUKATIF: JURNAL ILMU PENDIDIKAN

Research \& Learning in Education

https://edukatif.org/index.php/edukatif/index

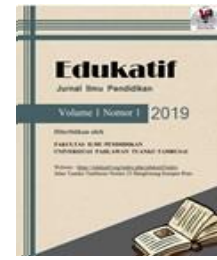

\title{
Meta Analisis Model Problem Based Learning $(P b L)$ terhadap Kemampuan Berpikir Kritis Siswa Sekolah Dasar
}

\author{
Irene Octavia Rossytasari ${ }^{1 凶}$, Eunice Widyanti Setyaningtyas ${ }^{2}$ \\ Universitas Kristen Satya Wacana, Indonesia ${ }^{1,2}$ \\ E-mail : 292017051@ student.uksw.edu ${ }^{1}, \underline{\text { eunice.widyanti@uksw.edu }}^{2}$
}

\begin{abstract}
Abstrak
Penelitian ini bertujuan untuk mengetahui besar pengaruh dari penggunaan model pembelajaran Problembased Learning $(P b L)$ ditinjau dari kemampuan berpikir kritis siswa sekolah dasar, dengan menganalisis 20 penelitian eksperimen yang sudah dipublikasi pada Google Scholar atau Google Cendekia. Penelitian ini menggunakan metode meta analisis. Tahapan meta analisis dalam penelitian ini antara lain; (a) menetapkan topik, (b) mencari dan mengumpulkan data, (c) melihat kesesuaian isi artikel dengan permasalahan. (d) menghitung signifikansi dengan menggunakan Uji T, (e) menghitung Effect Size, dan (f) menganalisis. Dari hasil analisis 20 artikel, berdasarkan Uji Paired Sample Test menunjukkan nilai Sig. (2-tailed) $(0,000)<\alpha$ $(0,05)$ dan $\mathrm{t}$ hitung $=-5,661<\mathrm{t}$ tabel $=2,093$ sehingga $\mathrm{H}_{\mathrm{o}}$ ditolak dan $\mathrm{H}_{\mathrm{a}}$ diterima, dan menghasilkan Effect Size 0,65 dengan kategori besar. Hasil effect size sebesar 0,65 mempunyai makna bahwa adanya perlakuan antar variable, artinya adanya perlakuan yang signifikan, model pembelajaran Problem-based Learning dalam membangun keterampilan berpikir kritis siswa SD. Hal tersebut menunjukan bahwa Problem-based Learning efektif digunakan untuk mengembangkan kemampuan berpikir kritis siswa.
\end{abstract}

Kata Kunci: Problem-based Learning, Berpikir Kritis, Meta Analisis.

\section{Abstract}

This study aims to determine the effect of using the Problem-based Learning (PbL) learning model in terms of critical thinking skills of elementary school students, by analyzing 20 experimental studies that have been published on Google Scholar or Google Scholar. This study uses a meta-analysis method. The stages of metaanalysis in this study include; (a) determine the topic, (b) search and collect data, (c) $\backslash$ see the suitability of the content of the article with the problem. (d) calculate the significance by using the T test, $(e)$ calculate the Effect Size, and (f) analyze. From the results of the analysis of 20 articles, based on the Paired Sample Test, the Sig. (2-tailed) $(0.000)<(0.05)$ and $t$ count $=-5.661<t$ table $=2.093$ so that Ho is rejected and Ha is accepted, and produces an Effect Size of 0.65 with a large category. The result of an effect size of 0.65 means that there is treatment between variables, meaning that there is a significant treatment, Problem-based Learning learning model in building critical thinking skills of elementary school students. This shows that Problem-based Learning is effectively used to develop students' critical thinking skills.

Keywords: Problem-based Learning, Critical Thinking, Meta Analysis.

Copyright (c) 2021 Irene Octavia Rossytasari, Eunice Widyanti Setyaningtyas

$\triangle$ Corresponding author:

Email :292017051@student.uksw.edu

DOI : https://doi.org/10.31004/edukatif.v3i4.1135

ISSN 2656-8063 (Media Cetak)

ISSN 2656-8071 (Media Online)

Edukatif : Jurnal Ilmu Pendidikan Vol 3 No 4 Tahun 2021 p-ISSN 2656-8063 e-ISSN 2656-8071 
2068 Meta Analisis Model Problem Based Learning (PbL) terhadap Kemampuan Berpikir Kritis Siswa Sekolah Dasar - Irene Octavia Rossytasari, Eunice Widyanti Setyaningtyas

DOI: https://doi.org/10.31004/edukatif.v3i4.1135

\section{PENDAHULUAN}

Kurikulum pendidikan di Indonesia adalah Kurikulum 2013 yang berfokus pada kemampuan berpikir siswa. Kurikulum ini menuntut siswa untuk berpikir tingkat tinggi dan kritis. Berpikir kritis berarti tindakan menanggapi informasi yang diterima dengan mempertimbangkan berbagai aspek yang berkaitan. Kemampuan berpikir kritis yaitu, kegiatan menganalisis ide atau gagasan ke arah yang lebih spesifik, membedakannya secara tajam, memilih, mengidentifikasi, mengkaji dan mengembangkannya ke arah yang lebih sempurna (Cece, 2010). Di beberapa daerah, permasalahan mengenai cara meningkatkan berpikir kritis siswa masih tergolong rendah, salah satu contoh permasalahan yang menjadi sorotan adalah rendahnya kemampuan berpikir kritis siswa yang disebabkan oleh berbagai hal, salah satunya adalah cara guru dalam mengajar. Metode yang dipakai guru dalam mengajar kurang meningkatkan kemampuan siswa dalam berpikir kritis. Hal ini didukung dengan penelitian yang dilakukan oleh Windayana pada tahun 2007 memperoleh hasil skor ratarata tes awal siswa yang hanya memperoleh 5,80, hal ini membuktikan bahwa kemampuan berpikir kritis siswa sekolah dasar masih rendah, selain itu terdapat guru yang pembelajarannya masih menggunakan metode atau model pembelajaran konvensional yang kurang tepat dalam membantu peningkatan kemampuan berpikir kritis pada siswa.

Terdapat berbagai macam metode atau model pembelajaran yang bertujuan untuk meningkatkan kemampuan berpikir kritis siswa, salah satunya adalah model pembelajaran berbasis masalah, contohnya model pembelajaran Problem-based Learning, model pembelajaran ini adalah model pembelajaran berbasis masalah, yang mana pada model pembelajaran ini siswa akan disuguhi dengan suatu konflik atau masalah, kemudian siswa akan mencari solusi untuk memecahkan masalah tersebut. Problem-based Learning merupakan suatu pembelajaran yang dapat mengembangkan keterampilan berpikir kritis terhadap siswa. Problem-based Learning adalah model pembelajaran yang memfokuskan pada pelacakan akar masalah dan memecahkan masalah tersebut (Abbudin, 2011). Pembelajaran berbasis masalah $(P b L)$ akan dapat membantu siswa mengembangkan keterampilan berpikir dan memecahkan masalah, mempelajari peran dari orang dewasa dan menjadi pembelajaran yang mandiri (Arends, Sani, 2014).

Pada pembelajaran yang menggunakan model pembelajaran Problem-based Learning $(P b L)$ dapat memberi dampak yang baik khususnya meningkatkan kemampuan berpikir kritis siswa. Beberapa peneliti melakukan penelitian terhadap model pembelajaran Problem-based Learning $(P b L)$ untuk membantu meningkatkan kemampuan berpikir kritis siswa pada sekolah dasar. Penelitian tersebut dilakukan untuk mengetahui seberapa besar efek atau pengaruh model pembelajaran Problem-based Learning ( $P b L$ ) terhadap kemampuan berpikir kritis maka perlu dilakukannya meta analisis yaitu mengambil rata-rata dari beberapa artikel penelitian eksperimen model Problem-based Learning $(P b L)$ terhadap kemampuan berpikir kritis siswa SD.

Hasil penelitian oleh Rani Nopia, dkk, yang dlakukan pada tahun 2016 dengan judul "Pengaruh Model Problem-based Learning terhadap Keterampilan Berpikir Kritis Siswa Sekolah Dasar Pada Materi Daur Air" dengan hasil penelitiannya menunjukan bahwa dengan penerapan model pembelajaran Problem-based Learning pada pembelajaran mampu meningkatkan kemampuan siswa dalam berpikir kritis, dibuktikan dengan rata - rata pretest kelas eksperimen adalah 35,5 sedangkan rata - rata posttest kelas eskperimen adalah 69. Dari hasil analisis yang telah dilakukan, bahwa model pembelajaran Problem-based Learning dapat meningkatkan kemampuan berpikir kritis siswa dari rata -rata yang terendah 2,10 hingga yang tertinggi 112,71, sedangkan hasil rata - rata sebelum dan sesudah menggunakan model Problem-based Learning mengalami peningkatan yang signifikan yaitu sebesar 32,67\%. Kemudian untuk hasil uji Effect size dengan menggunakan Uji T dapat dilihat dari hasil Paired Sample Test terdapat mean sebesar 16,38 dan Standart Deviation sebesar 12,94 dengan nilai Sig 0,000. Besaran Effect size yang diperoleh adalah sebesar 0,65 apabila dilihat dari tabel interpretasi Cohen's didapatkan bahwa model pembelajaran Problem-based Learning 
2069 Meta Analisis Model Problem Based Learning (PbL) terhadap Kemampuan Berpikir Kritis Siswa Sekolah Dasar - Irene Octavia Rossytasari, Eunice Widyanti Setyaningtyas

DOI: https://doi.org/10.31004/edukatif.v3i4.1135

berpengaruh besar terhadap kemampuan berpikir kritis siswa.

Permasalahan yang digunakan dalam penerapan model Problem-based Learning adalah dunia nyata (real-world), dengan masalah dapat membuat siswa mendapat pengalaman pembelajaran yang baru (new areas of learning), lebih mengutamakan belajar secara mandiri (self-directed learning), dapat memanfaatkan sumber secara kolaboratif dan komunikatif, serta dapat mengembangkan kemampuan pemecahan masalah sehingga kriteria tersebut dapat melatih perserta didik untuk mengenangkan keterampilan berpikir kritis. Pada penelitian terdahulu, belum menjumpai temuan khusus yang menarik pada interpretasinya, terutama faktor geografisnya yang telah dikaitkan pada dunia pendidikan di Indonesia ini, yang dapat menimbulkan pengaruh atau tidaknya terhadap hasil kemampuan berpikir kritis pada siswa, perlu adanya penelitian yang lebih lanjut mengenai pengaruh wilayah terhadap hasil belajar khusunya kemampuan berpikir kritis siswa. Oleh karena itu pada penelitian kali ini akan dibahas juga mengenai penggunaan model pembelajaran Problem-based Learning terhadap peningkatan kemampuan berpikir kritis siswa SD pada wilayah perkotaan dan pedesaan.

Berdasarkan diatas, dilakukan penelitian dengan judul "Meta Analisis Problem-based Learning $(P b L)$ Terhadap Kemampuan Berpikir Kritis Siswa Sekolah Dasar". Tujuan dari penelitian ini adalah untuk mengetahui besar pengaruh dari penggunaan model pembelajaran Problem-based Learning terhadap peningkatan kemampuan berpikir kritis siswa SD, melalui meta-analisis dari 20 penelitian eksperimen. Pada penelitian ini, digunakan 20 sampel berupa penelitian terdahulu dengan topik yang sejenis untuk dilakukan olah informasi yang ada dan dapat dianalisis besar pengaruh pada studi yang terdahulu. Hasil analisis data diharapkan dapat memberikan pengetahuan kepada guru untuk menggunakan model pembelajaran Problembased Learning dan mengembangkannya dengan fasilitas dan media dalam pembelajaran di kelas.

\section{METODE PENELITIAN}

Penelitian ini menggunakan metode meta analisis, karena adanya pandemi Covid-19 yang berdampak pada penerapan Pembelajaran Jarak Jauh di semua daerah. Meta analisis adalah suatu penelitian yang menganalisis berbagai penelitian yang mengarah pada permasalahan yang sama untuk mendapatkan kesimpulan secara umum dan luas (Wahyuningsih et al., 2019). Penelitian dengan menggunakan meta analisis, maka dapat diperoleh estimasi besarnya pengaruh pada subjek yang akan diteliti dengan cara merangkum beberapa jurnal penelitian, selain itu meta analisis merupakan studi yang lebih efektif dari pada peninjauan konvensional yang biasanya cenderung meringkas pada data kualitatifnya saja. Penelitian ini dilaksanakan pada bulan April - Juli 2021 di Fakultas Keguruan dan Ilmu Pendidikan Universitas Kristen Satya Wacana dengan alamat J1. Diponegoro No. 52-60 Salatiga, Kecamatan Sidorejo, Kota Salatiga, Jawa Tengah, 5071.

Populasi yang digunakan dalam penelitian ini adalah 20 artikel publikasi ilmiah yang berupa jurnal berskala nasional di Indonesia berisi tentang penggunaan model pembelajaran Problem-based Learning (PbL). Sampel yang diambil adalah artikel ilmiah Problem-based Learning terhadap kemampuan berpikir kritis siswa, dengan kategori sebagai berikut: (a) artikel dibuat oleh mahasiswa maupun peneliti; (b) artikel menggunakan metode penelitian eksperimen; (c) artikel merupakan penelitian kuantitatif yang memenuhi statistic Effect Size; (d) artikel diterbitkan 10 tahun terakhir; (e) sampel yang diambil merupakan jenjang Sekolah Dasar; dan (f) lingkup wilayah yang digunakan dalam peneltian ini adalah wilayah Indonesia.

Pengumpulan data dilakukan melalui media elektronik berupa internet yaitu dengan cara searching di Google Cendekia atau Google Scholar (https://scholar.google.co.id/) yang berisikan jurnal-jurnal nasional dan internasional yang sudah ada dengan kata kunci: Model Pembelajaran Problem-based Learning, Berpikir kritis siswa. Pada penelitian ini, tahapan - tahapan penelitian meta analisis yang digunakan adalah:

1. Menetapkan masalah atau topik yang hendak diteliti yaitu mengenai model pembelajaran Problem-based Learning terhadap pembelajaran di Sekolah Dasar. 
2070 Meta Analisis Model Problem Based Learning (PbL) terhadap Kemampuan Berpikir Kritis Siswa Sekolah Dasar - Irene Octavia Rossytasari, Eunice Widyanti Setyaningtyas

DOI: https://doi.org/10.31004/edukatif.v3i4.1135

2. Mencari dan mengumpulkan data berupa jurnal nasional yang berkaitan dengan masalah atau topik yang akan diteliti serta menentukan periode hasil temuan penelitian yang dijadikan data sumber yaitu dipublikasikan pada 2011-2020.

3. Membaca laporan penelitian untuk melihat kesesuaian isi dengan masalah yang telah ditentukan, memfokuskan penelitian pada masalah berupa aspek metodologi penelitian serta mengkategorikan masing-masing penelitian atau dengan kata lain mendata informasi sebanyak-banyaknya pada laporan penelitian.

4. Menghitung signifikansi dengan menggunakan Uji T.

5. Menghitung Effect Size pada setiap laporan penelitian dari masing-masing data yang didapat.

6. Menganalisis laporan penelitian yang sebelumnya telah dipublikasikan berdasarkan kajian metode dan analisis data yang digunakan, sehingga dapat ditarik kesimpulan.

Meta analisis digunakan untuk menghitung effect size, yang mana dalam penelitian ini menggunakan kalkulasi dengan teknik analisis effect size. Effect Size ialah skor yang mengambarkan besaran efek dari tindakan kekuatan antara dua variable. Adapun rumus yang digunakan untuk menguji Effect Size berdasarkan Cohen:

$$
d=\frac{M_{\text {posttest }}-M_{\text {pretest }}}{\sqrt{\frac{\left(S D_{\text {pretest }}{ }^{2}+S D_{\text {posttest }}{ }^{2}\right)}{2}}}
$$

Keterangan:

$$
\begin{array}{ll}
\mathrm{D} & =\text { Effect } \text { Size } \\
\mathrm{M}_{\text {pretest }} & =\text { mean pretest } \\
\mathrm{M}_{\text {posttest }} & =\text { mean posttest } \\
\mathrm{SD}_{\text {pretest }} & =\text { standar deviasi pretest } \\
\mathrm{SD}_{\text {posttest }} & =\text { standar deviasi posttest }
\end{array}
$$

Menurut Cohen, interprestasi Effect Size sebagai berikut:

Tabel 1

Interpretasi Effect Size Cohen's d

\begin{tabular}{cc}
\hline Effect Size & Interpretasi \\
\hline $0<\mathrm{d}<0,2$ & Kecil \\
\hline $0,2<\mathrm{d} \leq 0,5$ & Sedang \\
\hline $0,5<\mathrm{d} \leq 0,8$ & Besar \\
\hline $\mathrm{d}>0,8$ & Sangat Besar \\
\hline
\end{tabular}

Penelitian ini juga melakukan uji hipotesis yang digunakan bertujuan untuk mengetahui bahwa apakah hipotesis penelitian diterima atau ditolak. Hipotesis akan ditolak apabila pada nilai signifikan atau nilai probabilitas kesalahan $(\alpha)>0,05$, sebaliknya Hipotesis diterima apabila nilai signifikasi atau nilai probabilitas $(\alpha)<0,05$. Hipotesis yang akan diuji dalam penelitian ini sebagai berikut:

$\mathrm{H}_{\mathrm{o}} \quad$ Tidak terdapat pengaruh yang signifikan kemampuan Berpikir kritis siswa pada saat sebelum dan sesudah pembelajaran menggunakan metode Problem-based Learning

$\mathrm{H}_{\mathrm{a}} \quad$ Terdapat pengaruh yang signifikan kemampuan Berpikir kritis siswa antara sebelum dan sesudah pembelajaran menggunakan metode Problem-based Learning 
2071 Meta Analisis Model Problem Based Learning (PbL) terhadap Kemampuan Berpikir Kritis Siswa Sekolah Dasar - Irene Octavia Rossytasari, Eunice Widyanti Setyaningtyas

DOI: https://doi.org/10.31004/edukatif.v3i4.1135

\section{HASIL DAN PEMBAHASAN PENELITIAN}

\section{Menetapkan Masalah atau Topik yang Hendak Diteliti}

Di beberapa daerah, permasalahan mengenai cara meningkatkan berpikir kritis siswa masih tergolong rendah, salah satu contoh permasalahan yang menjadi sorotan adalah rendahnya kemampuan berpikir kritis siswa. Kemampuan berpikir kritis siswa sekolah dasar masih rendah dengan diperoleh hasil skor rata-rata tes awal siswa yang hanya memperoleh 5,80 (Windayana, 2007). Selain itu masih terdapat guru yang pembelajarannya menggunakan metode atau model pembelajaran konvensional yang kurang tepat dalam membantu peningkatan kemampuan berpikir kritis pada siswa. Penelitian ini dilakukan untuk mengetahui besar pengaruh dari penggunaan model pembelajaran Problem-based Learning terhadap kemampuan berpikir kritis siswa SD. Jenis penelitian yang digunakan dalam penelitian ini adalah meta analisis.

\section{Mencari dan Mengumpulkan Data}

Pengumpulan data dilakukan melalui berbagai sumber atau jurnal online dengan menggunakan Google Cendekia atau Google Scholar. Penelitian ini terbatas dengan menggunakan 20 artikel penelitian sejenis dimana didalam masing-masing penelitian tersebut terdapat hasil perolehan yang berbeda-beda. Di temukan artikel yang sesuai dengan kriteria, 20 artikel penelitian yang diperoleh memiliki tahun publikasi dari tahun 2014 - 2020, sampel yang digunakan juga terdiri dari kelas 4 dan 5 yang dilakukan pada pembelajaran tatap muka. Dari artikel yang diambil dari tahun 2014 - 2020, kemudian dilakukan pemberian kode pada setiap artikel atau jurnal tersebut, serta mengkategorikannya ke dalam SD wilayah perkotaan dan SD wilayah pedesaan. Data kode artikel disajikan sebagai berikut:

Tabel 2

Kode Artikel Sesuai dengan Kriteria Penelitian

\begin{tabular}{|c|c|c|c|c|c|}
\hline No & $\begin{array}{l}\text { Kode } \\
\text { Data }\end{array}$ & Judul & Nama & Tahun & $\begin{array}{l}\text { Metode } \\
\text { Problem-based } \\
\text { Learning }\end{array}$ \\
\hline 1. & K1 & $\begin{array}{l}\text { Pengaruh Problem-based Learning Terhadap } \\
\text { Keterampilan Berpikir Kritis dan Regulasi Diri } \\
\text { Siswa Kelas V }\end{array}$ & $\begin{array}{l}\text { Pricilia } \\
\text { Anindyta dan } \\
\text { Suwarjo }\end{array}$ & 2014 & $\checkmark$ \\
\hline 2. & $\mathrm{~K} 2$ & $\begin{array}{l}\text { Model Problem-based Learning Untuk } \\
\text { Menumbuhkan Kemampuan Berpikir Kritis } \\
\text { Siswa di Sekolah Dasar }\end{array}$ & $\begin{array}{l}\text { Ryky Mandar } \\
\text { Sari }\end{array}$ & 2015 & $\checkmark$ \\
\hline 3. & K3 & $\begin{array}{l}\text { Pengaruh penggunaan Model Problem Based } \\
\text { Learning Terhadap Karakter Kreatif dan } \\
\text { Berpikir Kritis Dalam Pembelajaran } \\
\text { Matematika }\end{array}$ & $\begin{array}{l}\text { Ujiati } \\
\text { Cahyaningsih } \\
\text { dan Anik } \\
\text { Gufron }\end{array}$ & 2016 & $\checkmark$ \\
\hline 4. & K4 & $\begin{array}{l}\text { Pengaruh Model Problem-based Learning } \\
\text { Terhadap Kemampuan Berpikir Kritis Siswa } \\
\text { pada Pembelajaran IPS di Sekolah Dasar }\end{array}$ & $\begin{array}{l}\text { Cahyatun } \\
\text { Nuchus }\end{array}$ & 2016 & $\checkmark$ \\
\hline 5. & K5 & $\begin{array}{l}\text { Pengaruh Model Problem-based Learning } \\
(P b L) \text { Terhadap Kemampuan Berpikir Kritis } \\
\text { Siswa SD }\end{array}$ & $\begin{array}{l}\text { Arnoldus } \\
\text { Helmon }\end{array}$ & 2018 & $\checkmark$ \\
\hline 6. & K6 & $\begin{array}{l}\text { Peningkatan Kemampuan Berpikir Kritis dan } \\
\text { Penguasaan Konsep IPA SD dengan } \\
\text { Menggunakan Model Problem-based Learning }\end{array}$ & $\begin{array}{l}\text { Widdy Sukma } \\
\text { Nugraha }\end{array}$ & 2018 & $\checkmark$ \\
\hline 7. & $\mathrm{~K} 7$ & $\begin{array}{l}\text { Keefektifan Problem-based Learning terhadap } \\
\text { Kemampuan Berpikir Kritis }\end{array}$ & $\begin{array}{l}\text { Muhammad } \\
\text { Aunur Rofiq }\end{array}$ & 2019 & $\checkmark$ \\
\hline 8. & K8 & $\begin{array}{l}\text { Efektivtas Problem-based Learning - Problem } \\
\text { Solving Terhadap Kemampuan Berpikir Kritis } \\
\text { Dalam Pembelajaran Matematika Siswa Kelas } \\
\text { V }\end{array}$ & Tri Puji Ati & 2020 & $\checkmark$ \\
\hline
\end{tabular}


2072 Meta Analisis Model Problem Based Learning (PbL) terhadap Kemampuan Berpikir Kritis Siswa Sekolah Dasar - Irene Octavia Rossytasari, Eunice Widyanti Setyaningtyas

DOI: https://doi.org/10.31004/edukatif.v3i4.1135

\begin{tabular}{|c|c|c|c|c|c|}
\hline No & $\begin{array}{l}\text { Kode } \\
\text { Data }\end{array}$ & Judul & Nama & Tahun & $\begin{array}{l}\text { Metode } \\
\text { Problem-based } \\
\text { Learning }\end{array}$ \\
\hline 9. & K9 & $\begin{array}{l}\text { Pengaruh Model Problem based } \\
\text { Learning }(P b L) \text { Terhadap Pemahaman Konsep } \\
\text { dan Keterampilan Berpikir Kritis Siswa Kelas } \\
\text { IV SDN Jambu Hilir Baluti } 2 \text { Pada Mata } \\
\text { Pelajaran Ilmu Pengetahuan Alam }\end{array}$ & Syahroni Ejin & 2020 & $\checkmark$ \\
\hline 10. & K10 & $\begin{array}{l}\text { Perbedaan Pengaruh Model Discovery } \\
\text { Learningdan Problem-based Learning } \\
\text { terhadap kemampuan Berpikir Kritis IPA } \\
\text { Siswa }\end{array}$ & $\begin{array}{l}\text { Ari Safitri dan } \\
\text { Yohana } \\
\text { Setiawan }\end{array}$ & 2020 & $\checkmark$ \\
\hline 11. & D1 & $\begin{array}{l}\text { Pengaruh Model Problem-based Learning } \\
\text { terhadap Ketrerampilan Berpikir Kritis Siswa } \\
\text { Sekolah Dasar Pada Materi Daur Air }\end{array}$ & Rani Nopia & 2016 & $\checkmark$ \\
\hline 12. & D2 & $\begin{array}{l}\text { Efektivitas } P b L \text { dan Problem Solving Siswa } \\
\text { SD Ditinjau dari Kemampuan Berpikir Kritis }\end{array}$ & $\begin{array}{l}\text { Misia dan } \\
\text { Mawardi }\end{array}$ & 2019 & $\checkmark$ \\
\hline 13. & D3 & $\begin{array}{l}\text { Keefektifan Model Problem- based Learning } \\
\text { terhadap kemampuan Berpikir Kritis Teama } \\
\text { Panas dan Perpindahannya }\end{array}$ & Salis Mahfudah & 2019 & $\checkmark$ \\
\hline 14. & D4 & $\begin{array}{l}\text { Efektivitas Problem-based Learning dan } \\
\text { Problem Solving terhadap kemampuan } \\
\text { Berpikir Kritis Siswa Kelas IV Dalam } \\
\text { Pembelajaran Matematika }\end{array}$ & $\begin{array}{l}\text { Elfa Pristy } \\
\text { Afifah }\end{array}$ & 2019 & $\checkmark$ \\
\hline 15. & D5 & $\begin{array}{l}\text { Pengaruh Model Pembelajaran Problem-based } \\
\text { Learning dengan Discovery Learning terhadap } \\
\text { Kemampuan Berpikir Kritis Siswa Kelas } 5 \text { SD }\end{array}$ & Fajar Prasetyo & 2020 & $\checkmark$ \\
\hline 16. & D6 & $\begin{array}{l}\text { Pengaruh Model Pembelajaran Problem-based } \\
\text { Learning Terhadap Kemampuan Berpikir } \\
\text { Kritis di Sekolah Dasar }\end{array}$ & $\begin{array}{l}\text { Fauza Rahmatia } \\
\text { dan Yanti Fitria }\end{array}$ & 2020 & $\checkmark$ \\
\hline 17. & D7 & $\begin{array}{l}\text { Pengaruh Moldel PbL Terhadap Kemampuan } \\
\text { Berpikir Kritis dan Pemahaman Konsep IPA } \\
\text { Siswa Kela V SDN } 30 \text { Sumpangbita }\end{array}$ & Abdul Rahman & 2020 & $\checkmark$ \\
\hline 18. & D8 & $\begin{array}{l}\text { Perbedaan Efektivitas Model Inquiry Learning } \\
\text { dengan Problem-based Learning terhadap } \\
\text { Kemampuan Berpikir Kritis Pada Pembelajran } \\
\text { Tematik Kelas IV }\end{array}$ & Elma Wijayanti & 2020 & $\checkmark$ \\
\hline 19. & D9 & $\begin{array}{l}\text { Pengaruh Model Problem-based Learning } \\
\text { Terhadap Kemampuan Berpikir Kritai Siswa } \\
\text { Kelas IV dalam Pmbelajaran Tematik }\end{array}$ & $\begin{array}{l}\text { Sri Wahyuni } \\
\text { dan Indri } \\
\text { Nugraheni }\end{array}$ & 2020 & $\checkmark$ \\
\hline 20. & D10 & $\begin{array}{l}\text { Efektivitas Model Problem Based Learning } \\
\text { dan Discovery Learning Terhadap } \\
\text { Kemampuan Berpikir Kritis Siswa Sekolah } \\
\text { Dasar }\end{array}$ & $\begin{array}{l}\text { Yudi Cahyo } \\
\text { Winoto dan } \\
\text { Tego Prasetyo }\end{array}$ & 2020 & $\checkmark$ \\
\hline
\end{tabular}

Dari artikel yang diambil dari tahun 2014 - 2020, kemudian pemberian kode pada setiap artikel atau jurnal tersebut. Artikel penelitian tersebut mengenai model pembelajaran Problem-based Learning untuk meningkatkan kemampuan berpikir kritis siswa SD. Pemberian kode disesuaikan dengan kategori penelitian SD di wilayah perkotaan dan pedesaan. Pemberian kode artikel dikategorikan menjadi 2 kategori yaitu kategori penelitian di wilayah perkotaan dan kategori penelitian di wilayah pedesaan. Kode K1-K10 adalah kategori artikel dengan wilayah penelitian di perkotaan dan kode D1-D10 adalah kategori artikel dengan wilayah penelitian di pedesaan. 
2073 Meta Analisis Model Problem Based Learning (PbL) terhadap Kemampuan Berpikir Kritis Siswa Sekolah Dasar - Irene Octavia Rossytasari, Eunice Widyanti Setyaningtyas

DOI: https://doi.org/10.31004/edukatif.v3i4.1135

\section{Melihat Kesesuaian Isi Artikel dengan Permasalahan}

Diperoleh 20 artikel yang terkait dengan model pembelajaran Problem-based Learning untuk meningkatkan kemampuan berpikir kritis siswa SD. Data dari 20 artikel tersebut diolah dengan cara merangkum dan menentukan intisari hasil penelitian. Kemudian data yang telah didapatkan dilaporkan kembali dengan cara deskriptif kualitatif dan kuantitatif. Berikut ini adalah data hasil analisis model Problembased Learning:

Tabel 3

Hasil Analisis Model Pembelajaran Problem-based Learning Terhadap Kemampuan Berpikir Kritis Siswa SD

\begin{tabular}{llllll}
\hline \multirow{2}{*}{ No } & Kode & \multicolumn{4}{c}{ Peningkatan Berpikir Kritis } \\
\cline { 3 - 6 } & Data & Pre Test & \multicolumn{1}{c}{ Post Test } & Gain & Gain\% \\
\hline 1. & K1 & 122,54 & 132,94 & 10,40 & 8,48 \\
\hline 2. & K2 & 5,00 & 6,17 & 1,17 & 23,4 \\
\hline 3. & K3 & 43,13 & 81,98 & 38,85 & 90,07 \\
\hline 4. & K4 & 61,03 & 83,61 & 22,58 & 36,99 \\
\hline 5. & K5 & 37,27 & 79,28 & 42,01 & 112,71 \\
\hline 6. & K6 & 14,73 & 26,37 & 11,64 & 79,02 \\
\hline 7. & K7 & 64,28 & 73,38 & 9,10 & 14,15 \\
\hline 8. & K8 & 71,00 & 79,00 & 8,00 & 11,26 \\
\hline 9. & K9 & 76,00 & 86,25 & 10,25 & 13,48 \\
\hline 10 & K10 & 67,61 & 69,03 & 1,42 & 2,10 \\
\hline 11. & D1 & 35,50 & 69,00 & 33,50 & 94,36 \\
\hline 12. & D2 & 72,88 & 86,11 & 13,23 & 18,15 \\
\hline 13. & D3 & 48,00 & 83,00 & 35,00 & 72,91 \\
\hline 14. & D4 & 64,22 & 85,83 & 21,61 & 33,64 \\
\hline 15. & D5 & 72,50 & 83,75 & 11,25 & 15,51 \\
\hline 16. & D6 & 47,29 & 52,43 & 5,14 & 10,86 \\
\hline 17. & D7 & 52,04 & 82,56 & 30,52 & 58,64 \\
\hline 18. & D8 & 76,00 & 81,00 & 5,00 & 6,57 \\
\hline 19. & D9 & 62,86 & 74,83 & 11,97 & 19,04 \\
\hline 20. & D10 & 69,60 & 74,60 & 5,00 & 7,18 \\
\hline Rata-Rata & 58,17 & 76,10 & 16,38 & 32,67 \\
\hline
\end{tabular}

Berdasarkan hasil analisis data dari beberapa jurnal yang diperoleh, pada tabel 3 dapat dilihat bahwa model pembelajaran Problem-based Learning mempunyai pengaruh yang signifikan terhadap kemampuan berpikir kritis siswa dengan rata - rata 16,38 yang dimulai dari peningkatan terendah 2,10 hingga yang tertinggi 112,71, serta hasil rata - rata sebelum dan sesudah menggunakan model Problem-based Learning mengalami peningkatan yang signifikan yaitu sebesar $32,67 \%$. 
2074 Meta Analisis Model Problem Based Learning (PbL) terhadap Kemampuan Berpikir Kritis Siswa Sekolah Dasar - Irene Octavia Rossytasari, Eunice Widyanti Setyaningtyas

DOI: https://doi.org/10.31004/edukatif.v3i4.1135

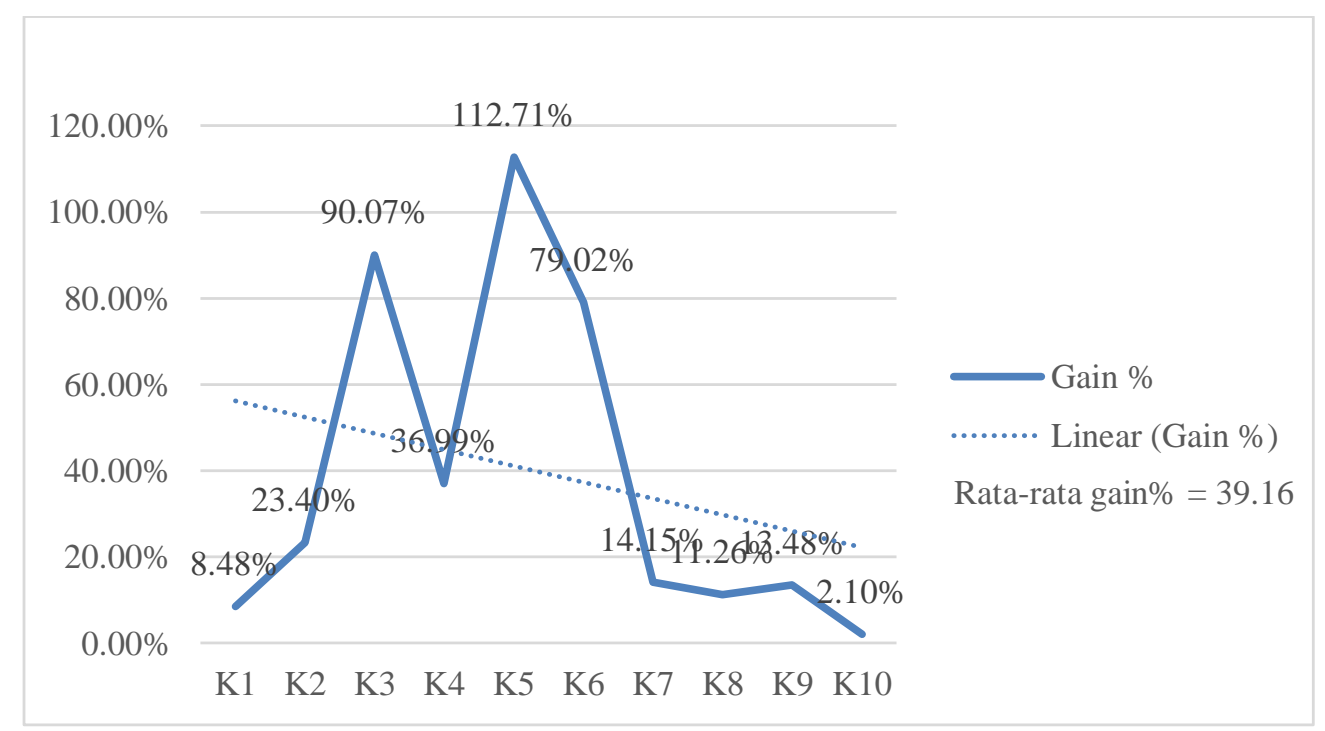

Grafik 1. Gain \% Model Pembelajaran Problem-based Learning Terhadap Kemampuan Berpikir Kritis Siswa SD di wilayah Perkotaan

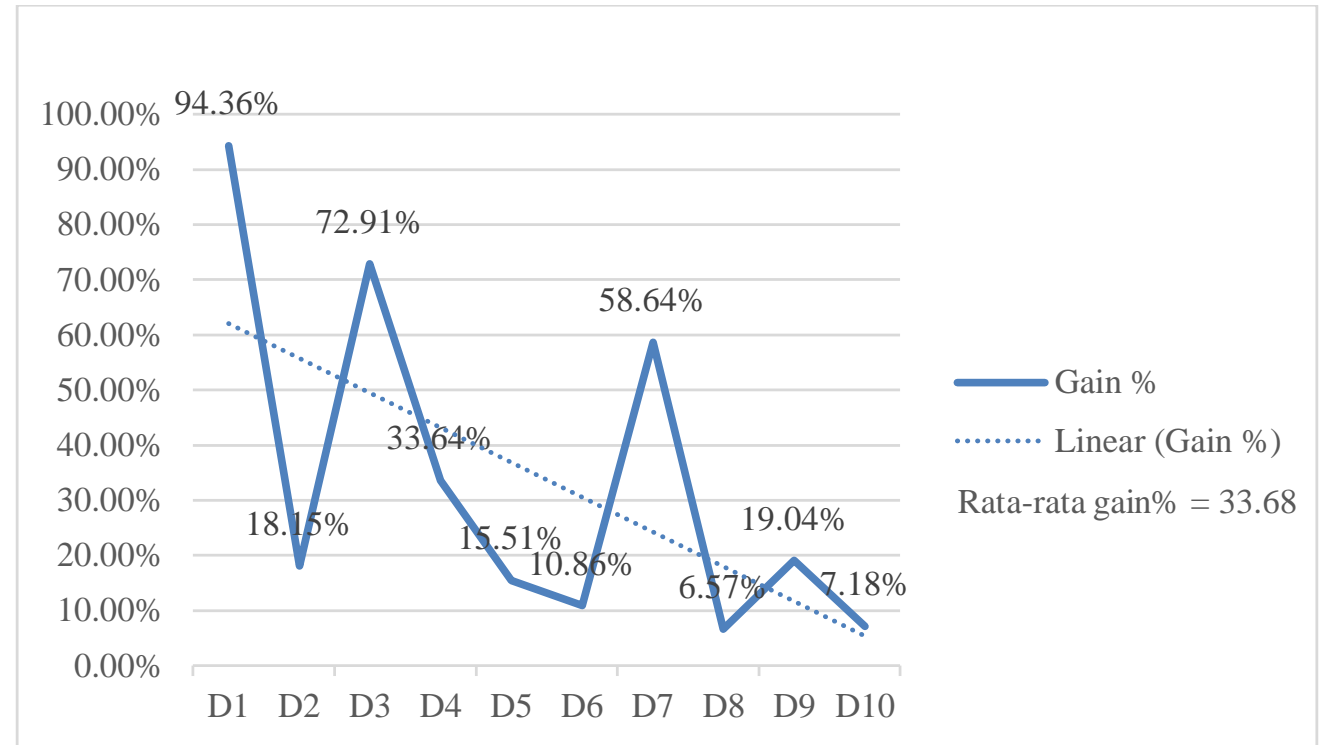

\section{Grafik 2. Gain \% Model Pembelajaran Problem-based Learning Terhadap Kemampuan Berpikir Kritis Siswa SD di wilayah Pedesaan}

Grafik 1 dan 2 diatas menunjukan presentase pola dari gain\% model pembelajaran Problem-based Learning terhadap kemampuan berpikir kritis siswa SD di wilayah perkotaan dan pedesaan. Pada grafik 1 dan 2 memiliki pola yang sama dari nilai gain\% terendah wilayah perkotaan sebesar $2.10 \%$, tertinggi $112.71 \%$, dan rata-rata yang diperoleh sebesar $39.16 \%$, sedangkan pada wilayah pedesaan gain $\%$ terendah sebesar $6.57 \%$, tertinggi $94.36 \%$, serta memperoleh rata-rata sebesar $33.68 \%$. Hal tersebut dapat diartikan bahwa dengan penggunaan model pembelajaran Problem-based Learning, kemampuan berpikir kritis siswa SD di wilayah perkotaan lebih tinggi dibandingkan dengan siswa SD di wilayah pedesaan. Agar tidak terjadi perbedaan yang signifikan dapat dilakukan dengan menarik minat siswa dengan penggunaan media pembelajaran pada penerapan model pembelajaran Problem-based Learning. 
2075 Meta Analisis Model Problem Based Learning (PbL) terhadap Kemampuan Berpikir Kritis Siswa Sekolah Dasar - Irene Octavia Rossytasari, Eunice Widyanti Setyaningtyas

DOI: https://doi.org/10.31004/edukatif.v3i4.1135

\section{Menghitung Signifikansi dengan Menggunakan Uji T (Paired Sample T-Test)}

Tabel 4

Tabel Paired Samples Statistic (Statistik Sampel Berpasangan)

\begin{tabular}{llllll}
\hline \multicolumn{5}{c}{ Paired Samples Statistics } \\
\hline \multirow{2}{*}{ Pair 1 } & PRETEST & 58.1740 & 20 & 24.91837 & 5.58191 \\
\cline { 2 - 6 } & POST TEST & 74.5560 & 20 & 24.96306 & 5.57192 \\
\hline
\end{tabular}

Berdasarkan hasil Output Paired-Sample T Test pada Tabel 4 menunjukkan bahwa Model Problembased Learning dapat meningkatkan kemampuan berpikir kritis dengan nilai rata-rata 58,1740 menjadi 74,5560 .

\section{Tabel 5}

Tabel Paired Samples Correlations (Korelasi Sampel Berpasangan)

\begin{tabular}{lllll}
\hline \multicolumn{5}{c}{ Paired Samples Correlations } \\
\hline & & N & Correlation & Sig. \\
\hline Pair 1 & PRETEST \& POSTTEST & 20 & .865 & .000 \\
\hline
\end{tabular}

Tabel 5 terlihat adanya hubungan antara kemampuan Berpikir kritis siswa rata-rata sebelum dengan sesudah menggunakan model pembelajaran Problem-based Learning sebesar 0,865. Hasil uji hipotesis, $\mathrm{H}_{\mathrm{o}}=$ dapat dilihat bahwa tidak terdapat perbedaan yang signifikan kemampuan Berpikir kritis siswa pada saat sebelum pembelajaran menggunakan metode Problem-based Learning dan $\mathrm{H}_{\mathrm{a}}=$ terdapat perbedaan yang signifikan Kemampuan bepikir Kritis siswa sesudah pembelajaran menggunakan metode Problem-based Learning.

Tabel 6

Tabel Paired Sample Test (Uji Sampel Berpasangan)

\begin{tabular}{|c|c|c|c|c|c|c|c|c|c|}
\hline \multicolumn{10}{|c|}{ Paired Samples Test } \\
\hline & & \multicolumn{5}{|c|}{ Paired Differences } & \multirow[t]{3}{*}{$\mathrm{T}$} & \multirow[t]{3}{*}{ Df } & \multirow{3}{*}{$\begin{array}{l}\text { Sig. (2- } \\
\text { tailed) }\end{array}$} \\
\hline & & \multirow[t]{2}{*}{ Mean } & \multirow[t]{2}{*}{$\begin{array}{l}\text { Std. } \\
\text { Deviatio } \\
\mathrm{n}\end{array}$} & \multirow[t]{2}{*}{$\begin{array}{l}\text { Std. } \\
\text { Error } \\
\text { Mean }\end{array}$} & \multicolumn{2}{|c|}{$\begin{array}{l}\text { 95\% Confidence } \\
\text { Interval of the } \\
\text { Difference }\end{array}$} & & & \\
\hline & & & & & Lower & Upper & & & \\
\hline $\begin{array}{l}\text { Pair } \\
1\end{array}$ & $\begin{array}{l}\text { PRETEST } \\
\text { - POST } \\
\text { TEST }\end{array}$ & $-\overline{16.38200}$ & 12.94225 & 2.89398 & -22.43916 & -10.32484 & $-\overline{5.661}$ & 19 & .000 \\
\hline
\end{tabular}

Tabel 6 menunjukkan nilai Sig. (2-tailed) $(0,000)<\alpha(0,05)$ dan $t$ hitung $=-5,661<\mathrm{t}$ tabel $=2,093$ sehingga $\mathrm{H}_{\mathrm{o}}$ ditolak dan $\mathrm{H}_{\mathrm{a}}$ diterima. Jadi, dapat disimpulkan bahwa terdapat pengaruh yang signifikan kemampuan berpikir kritis siswa sebelum dan sesudah menggunakan metode Problem-based Learning. Berdasarkan hasil analisis pada tiap penelitian dapat dilihat bahwa model pembelajaran Problem-based Learning mempunyai pengaruh terhadap keterampilan berpikir kritis siswa.

\section{Menghitung Effect Size}

Effect size dilakukan untuk menghitung besaran pengaruh dari penggunaan model pembelajaran Problem-based Learning terhadap kemampuan berpikir kritis siswa sekolah dasar. Diperoleh hasil hitung yang dilakukan oleh peneliti, tertera pada table 5 dengan perolehan skor mean pada pretest yaitu sebesar 58,1740 dengan standar deviasi 24.91837. Kemudian pada posttest, mean mengalami kenaikan yang signifikan menjadi sebesar 74.5560 dengan standar deviasi 24.96306. Berdasarkan dari data dapat dilakukan perhitungan menggunakan rumus effect size, sebagai berikut: 
2076 Meta Analisis Model Problem Based Learning (PbL) terhadap Kemampuan Berpikir Kritis Siswa Sekolah Dasar - Irene Octavia Rossytasari, Eunice Widyanti Setyaningtyas

DOI: https://doi.org/10.31004/edukatif.v3i4.1135

$$
\begin{aligned}
& d=\frac{M_{\text {posttest }}-M_{\text {pretest }}}{\sqrt{\frac{\left(S D_{\text {pretest }}{ }^{2}+S D_{\text {posttest }}{ }^{2}\right)}{2}}} \\
& d=\frac{\frac{74.5560-58,1740}{\sqrt{\frac{\left(24.96306^{2}+24.91837^{2}\right)}{2}}}}{d=\frac{16,382}{\sqrt{\frac{623,154364564+620,925163457}{2}}}} \\
& d=\frac{16,382}{\sqrt{\frac{1244,07952802}{2}}} \\
& d=\frac{16,382}{\sqrt{622,03976401}} \\
& d=\frac{16,382}{24,9407250097} \\
& d=0,65
\end{aligned}
$$

Berdasarkan perhitungan diatas didapatkan hasil besaran pengaruh yaitu sebesar 0,65 dan apabila dilihat pada tabel 1 mengenai interpretasi effect size masuk dalam kategori besar. Maka dapat disimpulkan bahwa dengan penggunaan model pembelajaran Problem-based Learning memiliki pengaruh yang besar terhadap kemampuan berpikir kritis siswa sekolah dasar.

\section{Menganalisis Laporan Penelitian}

Berdasarkan temuan dengan penggunaan model pembelajaran Problem-based Learning ini menghasilkan rata- rata dari keseluruhan penggunaan Problem-based Learning sebesar 0,65. Pada angka tersebut mempunyai makna bahwa adanya perlakuan antar variabel, artinya perlakuan model pembelajaran Problem-based Learning dalam membangun keterampilan berpikir kritis siswa SD. Penelitian ini hanya terbatas pada 20 artikel penelitian yang diambil dengan menggunakan sampel siswa sekolah dasar negeri dan swasta kelas 4 dan 5. Pada penelitian tersebut diperoleh bahwa penelitian tersebut sama-sama membuktikan hasil belajar dari perlakuan kelompok eksperimen model pembelajaran Problem-based Learning lebih tinggi dibanding dengan kelompok kontrol. Hasil tersebut dapat diperoleh dari ketepatan pendidik dalam memilih strategi pemecahan masalah, manajemen kelas, serta dukungan dari semua pihak menjadi bagian penting yang berpengaruh terhadap pencapaian belajar atau hasil belajar siswa.

Pada 20 artikel yang diambil dari tahun 2014 - 2020, kemudian dilakukan pemberian kode pada setiap artikel atau jurnal tersebut, serta mengkategorikannya ke dalam SD wilayah perkotaan dan SD wilayah pedesaan. Pengkategorian tersebut untuk melihat adanya perbedaan pengaruh model pembelajaran Problembased Learning terhadap kemampuan berpikir kritis siswa SD di wilayah perkotaan dan pedesaan yang disajikan dalam bentuk grafik. Para grafik 1 dan 2 dapat dilihat bahwa menunjukan presentase pola dari gain\% model pembelajaran Problem-based Learning terhadap kemampuan berpikir kritis siswa SD di wilayah perkotaan dan pedesaan. Pada grafik 1 dan 2 memiliki pola yang sama dari nilai gain\% terendah wilayah perkotaan sebesar $2.10 \%$, tertinggi $112.71 \%$, dan rata-rata yang diperoleh sebesar $39.16 \%$, sedangkan pada wilayah pedesaan gain $\%$ terendah sebesar $6.57 \%$, tertinggi $94.36 \%$, serta memperoleh rata-rata sebesar 33.68\%. Hal tersebut dapat diartikan bahwa dengan penggunaan model pembelajaran Problem-based Learning, kemampuan berpikir kritis siswa SD di wilayah perkotaan lebih tinggi dibandingkan dengan siswa SD di wilayah pedesaan. 
2077 Meta Analisis Model Problem Based Learning (PbL) terhadap Kemampuan Berpikir Kritis Siswa Sekolah Dasar - Irene Octavia Rossytasari, Eunice Widyanti Setyaningtyas

DOI: https://doi.org/10.31004/edukatif.v3i4.1135

Hasil Output Paired Sample T-Test pada tabel 4 menunjukan bahwa pembelajaran dengan penggunaan model pembelajaran Problem-based Learning dapat meningkatkan kemampuan berpikir kritis siswa sekolah dasar dengan nilai rata-rata 58,1740 menjadi 74,5560. Kemudian pada tabel 5 ditunjukan bahwa adanya hubungan antara kemampuan berpikir kritis siswa rata - rata sebelum dengan sesudah menggunakan model pembelajaran Problem-based Learning sebesar 0,865.

Hasil uji hipotesis, $\mathrm{H}_{0}=$ tidak terdapat perbedaan yang signifikan Problem-based Learning dan $\mathrm{H}_{\mathrm{a}}=$ terdapat perbedaan yang signifikan kemampuan berpikir kritis siswa sebelum pembelajaran menggunakan model Problem-based Learning. Tabel 6 menunjukkan nilai Sig. (2-tailed) $(0,000)<\alpha(0,05)$ dan $\mathrm{t}$ hitung $=$ 5,661 $<\mathrm{t}$ tabel $=2,093$, sehingga $\mathrm{H}_{\mathrm{o}}$ ditolak dan $\mathrm{H}_{\mathrm{a}}$ diterima. Jadi, dapat disimpulkan bahwa terdapat perbedaan yang signifikan kemampuan berpikir kritis siswa sebelum dan sesudah menggunakan Problembased Learning. Berdasarkan hasil analisis penelitian dapat dilihat bahwa kemampuan berpikir kritis siswa dapat ditingkatkan dengan menggunakan metode Problem-based Learning.

Berdasarkan dari hasil penelitian meta-analisis model pembelajaran Problem-based Learning terhadap kemampuan berpikir kritis siswa menghasilkan besar pengaruh (effect size) sebesar 0,65 yang termasuk dalam kategori besar. Hal tersebut menunjukan bahwa model pembelajaran Problem-based Learning efektif digunakan untuk mengembangkan kemampuan berpikir kritis siswa SD. Pengaruh model Problem-based Learning terhadap kemampuan berpikir kritis siswa terkait dengan kriteria model pembelajaran Problembased Learning itu sendiri untuk membantu peserta didik menyelesaikan masalah dalam dunia nyata. Model pembelajaran Problem Based Learning berpeluang untuk melatih dan mengembangkan keterampilan berpikir kritisnya. Tahapan Problem Based Learning diawali dengan orientasi siswa dengan masalah yang faktual, dan diakhiri dengan mengevaluasi proses pemecahan masalah. Siswa secara individual maupun berkelompok diharapkan dapat mengidentifikasi masalah, merumuskan strategi pemecahan masalah, menentukan keputusan dan kesimpulan, serta melakukan evaluasi. Pada tahap- tahap tersebut justru memberikan kesempatan kepada siswa untuk mengembangkan kemampuan berpikir kritis. Jika siswa memiliki kemampuan berpikir kritis maka siswa akan terampil dalam memecahkan masalah terutama pada kehidupan nyata, sehingga dari kemampuan berpikir kritis tersebut mampu menghasilkan variasi ide yang berguna dalam penyelesaian masalah. Maka dari itu aspek atau indikator berpikir kritis yang berperan penting sebelum menghasilkan kesimpulan dari semua strategi penyelsaian masalah adalah pada tahapan menyusun strategi pemecahan masalah yang dikumpulkan, pada tahap ini sangat penting karena melalui tahap tersebut siswa akan menghasilkan banyak jawaban atau strategi yang luas, dari situ siswa akan semakin meningkatnya keterampilan berpikir kritis. Model pembelajaran Problem-based Learning dapat membiasakan siswa menghadapi dan bagaimana cara memecahkan masalah secara terampil, yang dapat pula mereka gunakan pada saat menghadapi masalah yang sesungguhnya di dalam kehidupan bermasyarakat (Abbudin, 2011). Siswa tidak selalu mengandalkan ingatan mereka saja, disebabkan karena karakteristik dari sintaks model pembelajaran yang menuntut siswa untuk bertanggung jawab secara individu atas keputusannya dan adanya komunikasi pada proses diskusi dalam proses penyelesaian masalah.

Hasil penelitian yang telah didapat sejalan dengan penelitian yang dilakukan oleh Safitri \& Setiawan pada tahun 2013 dengan judul "Perbedaan Pengaruh Model Discovery Learning dan Problem-based Learning terhadap kemampuan Berpikir Kritis IPA Siswa", dalam hasil pembahasannya menunjukan bahwa terdapathasil uji normalitas signifikasi nilai pretest Problem-based Learning adalah 0,053>0,05 maka dapat diartikan berdistribusi normal. Tingkat signifikasi nilai posttest adalah 0,143>0,05 maka dapat diartikan berdistribusi normal. Rata - rata dari nilai pretest $\mathrm{PbL}$ adalah 68,97 sedangkan posttestnya adalah 74,97. Problem-based Learning adalah model yang efektif untuk digunakan dalam meningkatkan kemampuan berpikir kritis siswa. Penelitian ini dapat menjadi pengetahuan bagi guru mengenai keefektifan menggunakan model pembelajaran Problem Based Learning terhadap kemampuan berpikir kritis siswa SD yang mana model pembelajaran ini dapat digunakan sebagai acuan dalam proses pembelajaran dikelas, menambah 
2078 Meta Analisis Model Problem Based Learning (PbL) terhadap Kemampuan Berpikir Kritis Siswa Sekolah Dasar - Irene Octavia Rossytasari, Eunice Widyanti Setyaningtyas

DOI: https://doi.org/10.31004/edukatif.v3i4.1135

pengetahuan dengan membuat perangkat pembelajaran, melaksanakan kegiatan pembelajaran, dan melakukan evaluasi pada model pembelajaran dalam mengembangkan kemampuan bepikir kritis, sehingga guru dapat mengajak siswa untuk ikut berperan aktif dalam proses pembelajaran.

\section{KESIMPULAN}

Tujuan dari penelitian ini adalah untuk mengetahui besar pengaruh dari penggunaan model pembelajaran Problem-based Learning $(\mathrm{PbL}$ ) ditinjau dari kemampuan berpikir kritis siswa sekolah dasar dengan menggunakan metode meta analisis. Penelitian ini hanya terbatas pada 20 penelitian eksperimen yang sudah dipublikasi pada Google Scholar atau Google Cendekia. Berdasarkan hasil analisis yang telah dilakukan, bahwa model pembelajaran Problem-based Learning dapat meningkatkan kemampuan berpikir kritis siswa dengan hasil rata - rata sebelum dan sesudah menggunakan model Problem-based Learning mengalami peningkatan yang signifikan yaitu sebesar 32,67\%. Perolehan Gain\% model pembelajaran Problem-based Learning terhadap kemampuan berpikir kritis siswa SD sedikit berbeda dengan rata-rata di wilayah perkotaan sebesar 39.16\% dan pedesaan sebesar 33.68\%. Hasil uji Effect size yang diperoleh adalah sebesar 0,65 dilihat dari tabel interpretasi Cohen's termasuk dalam kategori besar artinya adanya perlakuan yang signifikan, model pembelajaran Problem-based Learning dalam membangun keterampilan berpikir kritis siswa SD. Hal tersebut menunjukan bahwa Problem-based Learning efektif digunakan untuk mengembangkan kemampuan berpikir kritis siswa. Hasil penelitian ini dapat digunakan sebagai bahan pertimbangan guru dalam penerapan model pembelajaran Problem-based Learning terhadap kemampuan berpikir kritis siswa dengan melihat perbedaan hasil belajar dalam berpikir kritis di wilayah perkotaan dan pedesaan.

\section{UCAPAN TERIMA KASIH}

Peneliti mengucapkan syukur kepada Tuhan Yang Maha Esa yang telah memberikan rahmat dan kemudahan dalam menyelesaikan artikel penelitian ini. Tak lupa mengucapkan terima kasih kepada kedua orang tua yaitu Bapak Yosef dan Ibu Ida karena telah memberikan semangat, dukungan, doa, dan motivasi. Terima kasih kepada dosen pembimbing, Ibu Eunice Widyanti Setyaningtyas, S.Pd., M.Pd. yang telah memberikan bimbingan dan arahan. Terima kasih juga kepada sahabat-sahabat saya yang telah memberikan motivasi dan semangat, serta ucapan terima kasih kepada pihak-pihak yang telah membantu dalam proses penyelesaian penelitian.

\section{DAFTAR PUSTAKA}

Abdurrozak, R., Jayadinata, A. K., \& Isrok'atun. (2016). Pengaruh Model Problem Based Learning terhadap Kemampuan Berargumentasi dan Hasil Belajar Siswa. Jurnal Pena Ilmiah, 1(1).

Abuddin, Nata. (2011). Manajemen Pendidikan, Mengatasi Kelemahan Pendidikan di Indonesia. Jakarta: Kencana Prenada Media Group.

Anindyta, P., \& Suwarjo, S. (2014). Pengaruh Problem Based Learning terhadap Keterampilan Berpikir Kritis dan Regulasi Diri Siswa Kelas V. Jurnal Prima Edukasia, 2(2). https://doi.org/10.21831/jpe.v2i2.2720

Ati, T. P., \& Setiawan, Y. (2020). Efektivitas Problem Based Learning-Problem Solving Terhadap Kemampuan Berpikir Kritis dalam Pembelajaran Matematika Siswa Kelas V. Jurnal Cendekia: Jurnal Pendidikan Matematika, 4(1), 294-303. https://doi.org/10.31004/cendekia.v4i1.209

Cahyaningsih, U., \& Ghufron, A. (2016). Pengaruh Penggunaan Model Problem-Based Learning terhadap Karakter Kreatif dan Berpikir Kritis dalam Pembelajaran Matematika. Jurnal Pendidikan Karakter, 1. https://doi.org/10.21831/jpk.v0i1.10736

Cece, Wijaya. (2010). Pendidikan Remidial: Sarana Pengembangan Mutu Sumber Daya Manusia. Bandung: PT Remaja Rosdakarya. 
2079 Meta Analisis Model Problem Based Learning (PbL) terhadap Kemampuan Berpikir Kritis Siswa Sekolah Dasar - Irene Octavia Rossytasari, Eunice Widyanti Setyaningtyas

DOI: https://doi.org/10.31004/edukatif.v3i4.1135

Demirel, M., \& Dağyar, M. (2016). Effects of Problem-Based Learning on Attitude: A Meta-analysis Study. EURASIA Journal of Mathematics, Science and Technology Education, 12(8). https://doi.org/10.12973/eurasia.2016.1293a

Djariyo, Ihtiya Kusuma Dewi, R. M. S. (2015). Model Problem Based Learning untuk Menumbuhkan Kemampuan Berpikir Kritis Siswa di Sekolah Dasar. Malih Peddas (Majalah Ilmiah Pendidikan Dasar), 3(2). https://doi.org/10.26877/malihpeddas.v5i2.847

Ejin, S. (2017). Pengaruh Model Problem Based Learning (PBL Terhadap Pemahaman Konsep dan Keterampilan Berpikir Kritis Siswa Kelas IV SDN Jambu Hilir Baluti 2 Pada Mata Pelajaran Ilmu Pengetahuan Alam. Jurnal Pendidikan (Teori Dan Praktik), 1(1). https://doi.org/10.26740/jp.v1n1.p6672

Fauza, R., \& Fitria, Y. (2020). Pengaruh Model Pembelajaran Problem Based Learning Terhadap Kemampuan Berpikir Kritis di Sekolah Dasar. Jurnal Pendidikan Tambusai, 4(3).

Helmon, A. (2018). Pengaruh Model Problem Based Learning (PBL) terhadap Kemampuan Berpikir Kristis Siswa SD. Jurnal Inovasi Pendidikan Dasar, 2(1).

Mahfudah, S., Susatyo, A., \& Widyaningrum, A. (2019). Keefektifan Model Problem Based Learning terhadap Kemampuan Berpikir Kritis Tema Panas dan Perpindahannya. Thinking Skills and Creativity Journal, 2(1). https://doi.org/10.23887/tscj.v2i1.18378

Misla, M., \& Mawardi, M. (2020). Efektifitas PBL dan Problem Solving Siswa SD Ditinjau dari Kemampuan Berpikir Kritis. Jurnal Ilmiah Sekolah Dasar, 4(1). https://doi.org/10.23887/jisd.v4i1.24279

Nopia, R., Julia, J., \& Sujana, A. (2016). Pengaruh Model Problem Based Learning terhadap Keterampilan Berpikir Kritis Siswa Sekolah Dasar pada Materi Daur Air. Jurnal Pena Ilmiah, 1(1). https://doi.org/10.23819/pi.v1i1.2996

Nuchus, C. (2016). Pengaruh Model Problem Based Learning terhadap Kemampuan Berpikir Kritis Siswa Pada Pembelajaran IPS di Sekolah Dasar. Jurnal Penelitian Pendidikan Guru Sekolah Dasar, 4(2).

Nugraha, W. S. (2018). Peningkatan Kemampuan Berpikir Kritis dan Penguasaan Konsep IPA Siswa SD dengan Menggunakan Model Problem Based Learning. Edu Humaniora|Jurnal Pendidikan Dasar Kampus Cibiru, 10(2). https://doi.org/10.17509/eh.v10i2.11907.

Prasetyo, F., \& Kristin, F. (2020). Pengaruh Model Pembelajaran Problem Based Learning dan Model Pembelajaran Discovery Learning terhadap Kemampuan Berpikir Kritis Siswa Kelas 5 SD. DIDAKTIKA TAUHIDI: Jurnal Pendidikan Guru Sekolah Dasar, 7(1). https://doi.org/10.30997/dt.v7i1.2645

Rahman, A., Khaeruddin, \& Ristiana, E. (2020). Pengaruh Model PBL Terhadap Kemampuan Berpikir Kritis dan Pemahaman Konsep IPA Siswa Kelas V SDN 30 Sumpangbita. Edumaspul: Jurnal Pendidikan, 4(1).

Rofiq, M. A. (2019). Keefektifan Problem Based Learning terhadap Kemampuan Berpikir Kritis. Jurnal BELAINDIKA (Pembelajaran Dan Inovasi Pendidikan), 1(2).

Safitri, A., \& Setiawan, Y. (2013). Perbedaan Pengaruh Model Discovery Learning Dan Problem Based Learning Terhadap. Jurnal Tematik Universitas Negeri Medan, 10.

Sani, K. (2014). Model Pembelajaran. Yogyakarta: Kata Pena.

Wahyuningsih, S. S., Darmayanti, T., Bintarti, A., \& Terbuka, U. (2019). Meta Analisis Tutorial Online. Jurnal Pendidikan Terbuka Dan Jarak Jauh, Vol.20(No.1 Maret).

Wijayanti, E., \& Indarini, E. (2020). Perbedaan Efekivitas Model Inquiry learning Dengan Problem based learning Terhadap Kemampuan Berpikir Kritis Pada Pembelajaran Tematik Kelas IV. Jurnal Ilmiah Wahana Pendidikan, 6(2). https://doi.org/10.5281/zenodo.3737205

Windayana, H. (2007). Pembelajaran Matematika Realistik dalam Meningkatkan Kemampuan Berpikir Logis, 
2080 Meta Analisis Model Problem Based Learning (PbL) terhadap Kemampuan Berpikir Kritis Siswa Sekolah Dasar - Irene Octavia Rossytasari, Eunice Widyanti Setyaningtyas

DOI: https://doi.org/10.31004/edukatif.v3i4.1135

Kreatif, dan Kritis, Serta Komunikasi Matematik Siswa Sekolah Dasar. Jurnal Pendidikan Dasar.

Winoto, Y. C., \& Prasetyo, T. (2020). Efektivitas Model Problem Based Learning dan Discovery Learning terhadap Kemampuan Berpikir Kritis Siswa Sekolah Dasar. Jurnal Basicedu, 4(2).

https://doi.org/10.31004/basicedu.v4i2.348 